\title{
'Pakarena' dance image classification using convolutional neural network algorithm
}

\author{
Abdul Ibrahima a, 1, *; Rachmat ${ }^{\text {b, } 2}$ \\ ${ }^{a}$ STMIK Dipanegara, Perintis Kemerdekaan Km. 9, Makassar 90245, Indonesia \\ ${ }^{b}$ Politeknik Informatika Nasional, Sultan Alauddin No. 250, Makassar 90245, Indonesia \\ ${ }^{1}$ abdulibrahim@dipanegara.ac.id; ${ }^{2}$ rachmat27udinus@gmail.com; \\ * Corresponding author
}

Article history: Received March 19, 2021; Revised July 04, 2021; Accepted July 04, 2021; Available online August 07,2021

\begin{abstract}
One of the riches of the Indonesian nation comes from the diversity of ethnicities and cultures, especially dance, which is the culture of the Indonesian people, starting from their ancestors until now, their authenticity is still maintained. The wrong cultural dance that develops, especially in South Sulawesi, which consists of four (4) ethnic groups, namely: Bugis, Makassar, Toraja and Mandar, which have their own dance dances from each tribe in South Sulawesi to maintain this dance. There is a need for collaboration between local community leaders, government and researchers, especially researchers to raise dance dances from the Makassar Tribe called Pakkarena dance using the Convolutional Neural Network (CNN) method to the Pakarena dance image in distinguishing or classifying an object on digital images with an accuracy level of $9575 \%$.
\end{abstract}

Keywords: Makassar Community Dance; Convolutional Neural Networks; Image

\section{Introduction}

The purpose of this study is to classify images, especially dance images which are the culture of the Indonesian nation so that an area can recognize or identify dance images that have a lot of dances to distinguish dance images, the authors conducted research on dance images in order to distinguish the dances of each tribe, namely in an area, especially in the province of South Sulawesi, by knowing the movements and tools used by the dancers, we will be able to immediately know that this dance comes from a certain area. Every human being has limitations in understanding information, especially digital images, so the author tries to engineer the characteristics of dance images so that they can be understood thoroughly starting from different points of view, differences in priority scales, lighting differences, and object positions [1][2].

Convolutional Neural Network is a method that can be used to detect and recognize an object in a digital image and is also a branch of machine learning. Part of the input layer and output layer so that this network is called Deep Learning [3]. The use of Deep Learning is increasingly being used in the field of research because of its very strong computational factors, very large data sets, and also the techniques used are very good in object detection and object recognition [4]. CNN's ability is claimed to be the best model to solve the problem of object detection and object recognition. In 2012, Research on CNN was able to perform digital image recognition with an accuracy that rivals' humans on certain datasets. However, CNN like other deep learning models has a weakness, namely the model training process is quite long [5].

The advantage of using ANN is to study the relationship between the input layer and the output layer to get the full hidden layer of each system built. In addition, modeling with ANN has the desired attributes and the ability to learn from examples without requiring explicit physical data. ANN is part of Machine Learning which is an artificial intelligence that aims to optimize the performance of a system by studying sample data or historical data [6].

ANN is widely used to solve problems related to research in the field of image detection and overall image processing called Multi-Layer Perceptron (MLP) which functions to fully connect between neurons. This MLP ability can be quite strong. However, this classification technique using MLP has a weakness, namely the input in the form of images. Images must be preprocessed, segmented, and extracted for optimal performance. Another MLP development that can overcome problems in object recognition is (CNN) [7]. 


\section{Method}

\section{A. Pakarena Dance}

Before it became the current form of Pakarena dance show in Figure 1, it was known as Sere Jaga which was part of a community ritual ceremony before planting rice and after planting rice. Where the dancers hold a bunch of quality rice (rice seeds that have been selected through a ceremony) which is considered the goddess of rice. Then the Sere Jaga dance developed into a ritual ceremony carried out throughout the night in welcoming the rice harvest ceremony. These ceremonies include ammatamata jene, benteng ammata, and others.

The existence of art in Indonesia cannot be separated from mystical stories at that time. This can also be seen in the arts from the South Sulawesi region, namely the Pakarena Dance. The beginning of its emergence cannot be predicted with certainty because there are only oral stories that are passed down from generation to generation. Pakarena dance originated from a myth about the separation between the inhabitants of the Land of Heaven and the inhabitants of the Ancient Earth. Before parting ways, Boting Langi taught the Lino people how to live, grow crops, raise livestock, and hunt through hand, body and foot movements. These movements then become ritual dances when the community expresses its gratitude to the residents. Another story mentions that the Pakarena dance is associated with legend as the first Somba (king) of the Kingdom of Gowa. It is said that Pakarena first appeared with Putri Tumanurung ri Tamalatea. According to the story, Pakarena is a companion and complement to the greatness of Tumanurung ri Tamalate [9].
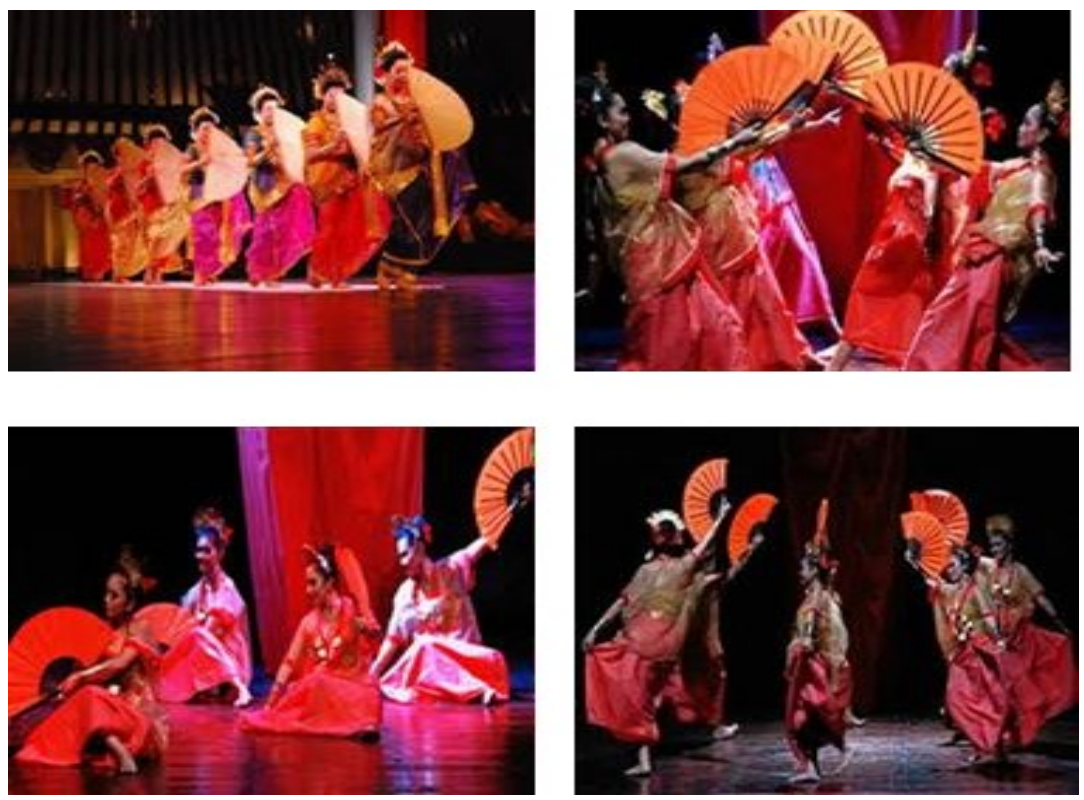

Figure 1. Pakarena Dance

\section{B. Convolutional Neural Network}

The technique used in overcoming this ANN problem is used for image processing, classification and image grouping, in this case dance images that can directly perform image processing. ANN is an adaptive system that can change its structure to solve problems based on external and internal information flowing through the network. In other words, this technique has the ability to remember from previous experiences [10][11].

The artificial neural network also has several layers commonly known as Multi-Layer Perceptron (MLP) which fully connects between neurons that have strong classification capabilities. However, MLP also has some problems when the input is an image. Images need to be preprocessed, segmented and feature extracted for optimal performance to get perfect results. This can also result in MLP having too many independent parameters or information redundancy in its architecture. The independent parameters are derived from a formation with a full connection scheme between inputs and some feature maps from input values to output values [12].

$s(g p-g c)^{2}=\sum_{p=0}^{1} s(g p-g c) 2 p$

Where:

p: Number of neighbors

$s$ : Radius of circular neighbors

$g c$ : Pixel center intensity value

$g p$ : neighbor intensity value 
Pass-forward network 3-2-3-2; it contains three nodes in the input layer (layer 0), two nodes in the first hidden layer (layer 1), three nodes in the second hidden layer (layer 2), and two nodes in the output layer (layer 3). This network, generally with no more than four such layers, is one of the most commonly used neural networks, so some users identify the phrase "neural network" to mean a feed-forward network. Conceptually, nodes in a higher layer successively abstract higher-level features from the previous layer. In the literature on neural networks, the term "feed forward" is sometimes used to refer to layered or acrylic tissues [13].

$$
\begin{aligned}
& \mathrm{V}^{k}=\sum_{j=1}^{p} W^{k j} X^{k} \\
& f(x)=\sum_{i=1}^{n} x^{k} a^{n-k}=\sum_{k=0}^{n}\left(\begin{array}{l}
n \\
k
\end{array}\right) x^{k} a^{n-k}
\end{aligned}
$$

\section{Experiment Design}

This experimental design contains the movement of the Pakarena dance which includes seven movements, including: walking along the beach, entertaining or serving guests, Waves with a loud voice, Opening, Grounding, show in Figure 2. Then the dataset was tested using the MATLAB 2020 program application [14].

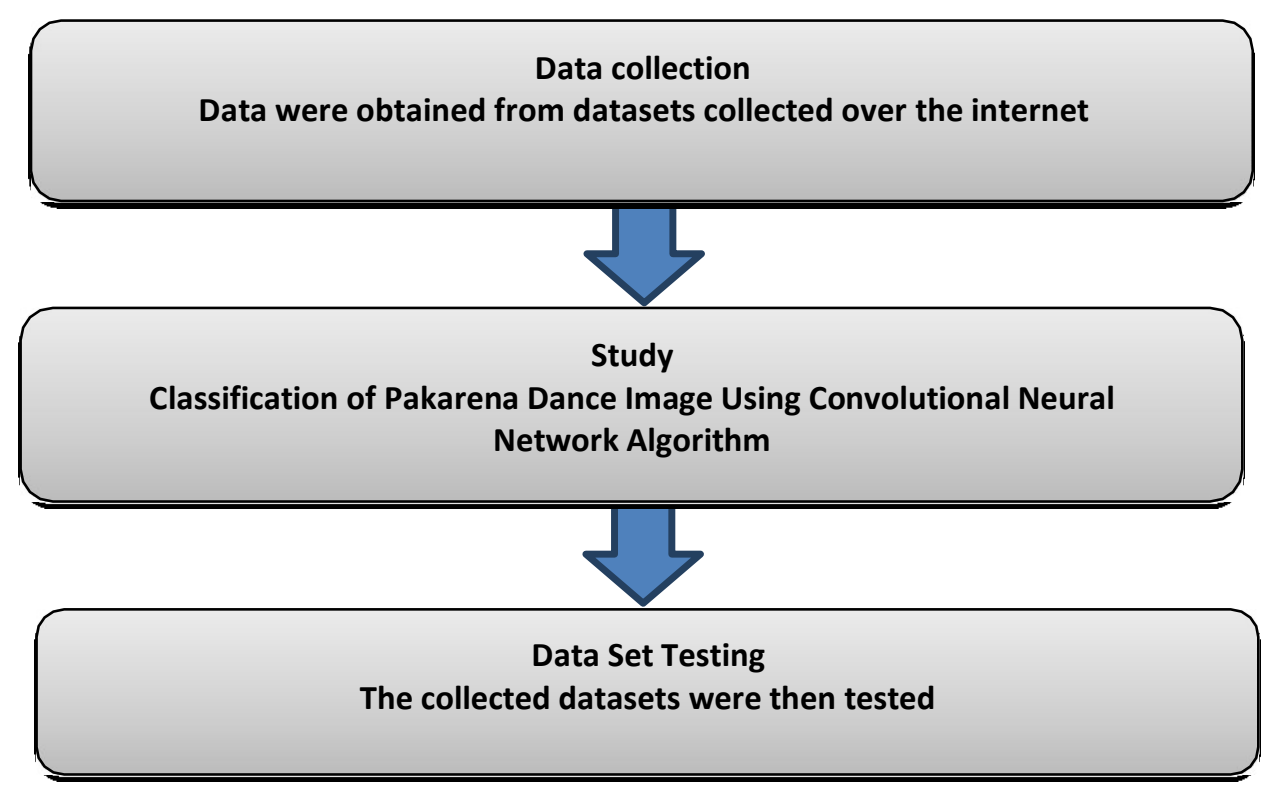

Figure 2. Experiment Design

\section{Results and Discussion}

The results of this discussion can be seen where the results of dance movements are carried out in real time, which can be seen in the dance movement model and then converted into a matrix with a diagonal value of 0 which is obtained in Figure 3. Then testing the image in real time by changing the diagonal value by 1 then it is obtained in Figure 4.
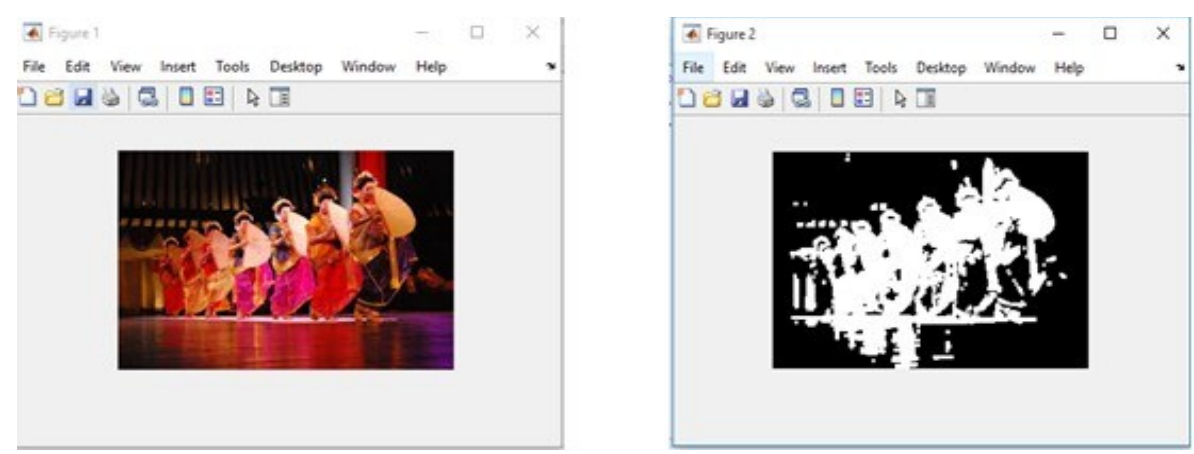

\begin{tabular}{|l|l|l|}
\hline 1 & 1 & 1 \\
\hline 1 & 0 & 1 \\
\hline 1 & 1 & 1 \\
\hline
\end{tabular}

Figure 3. the dance movement model and then converted into a matrix with a diagonal value of 0 

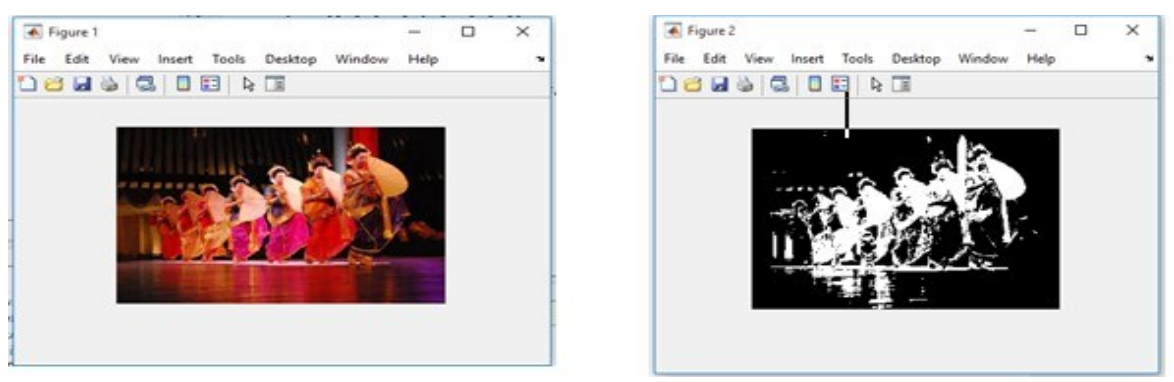

\begin{tabular}{|l|l|l|}
\hline 0 & 0 & 0 \\
\hline 0 & 1 & 0 \\
\hline 0 & 0 & 0 \\
\hline
\end{tabular}

Figure 4. the dance movement model and then converted into a matrix with a diagonal value of 1

Based on the results and discussion above, the diagonal value of 1 in the classification of pakarena dance is very clear compared to the diagonal value of 0 . This means that the classification of pakarena dance must have good lighting.

Tabel 1. Test Results Data Testing

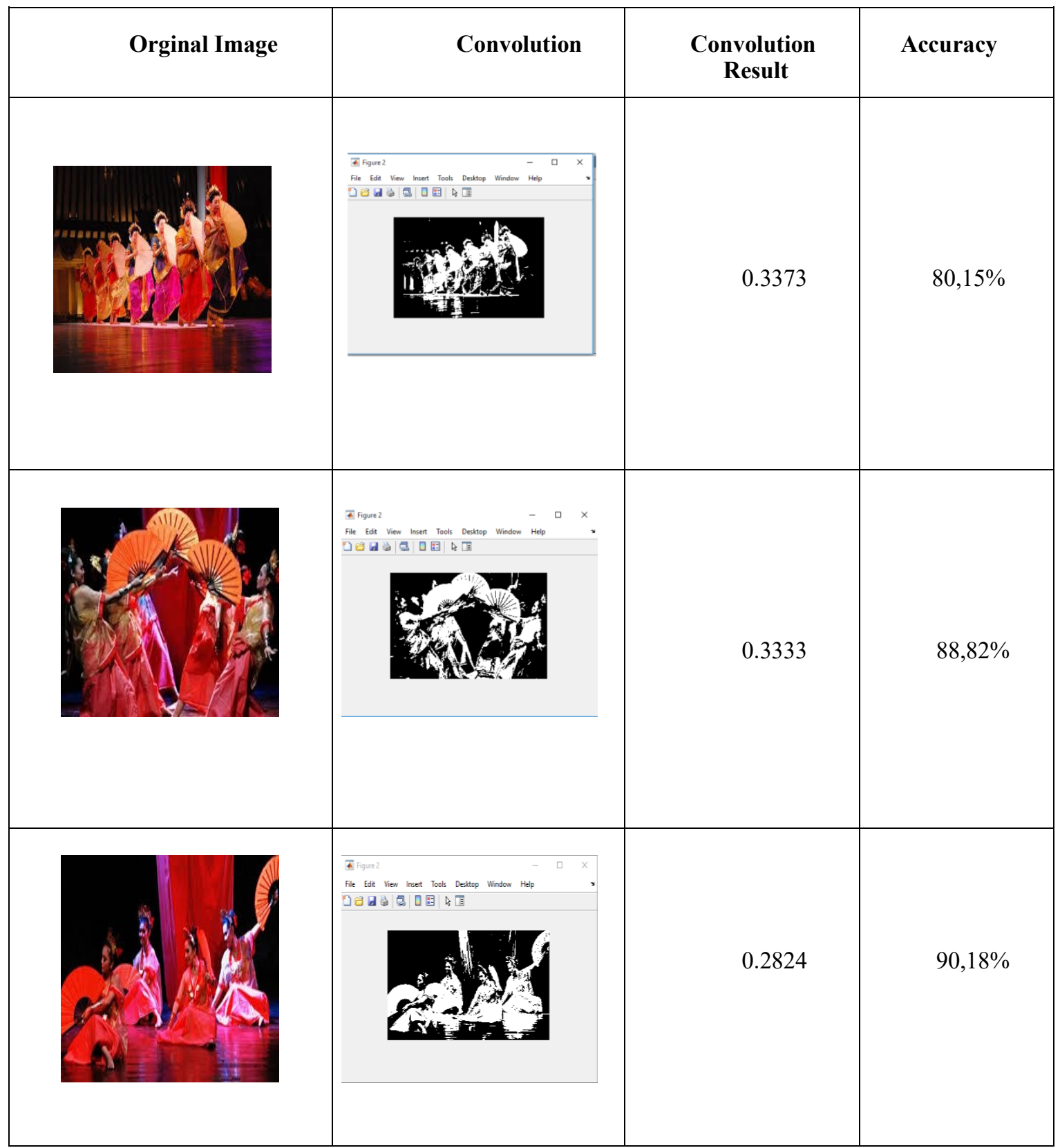




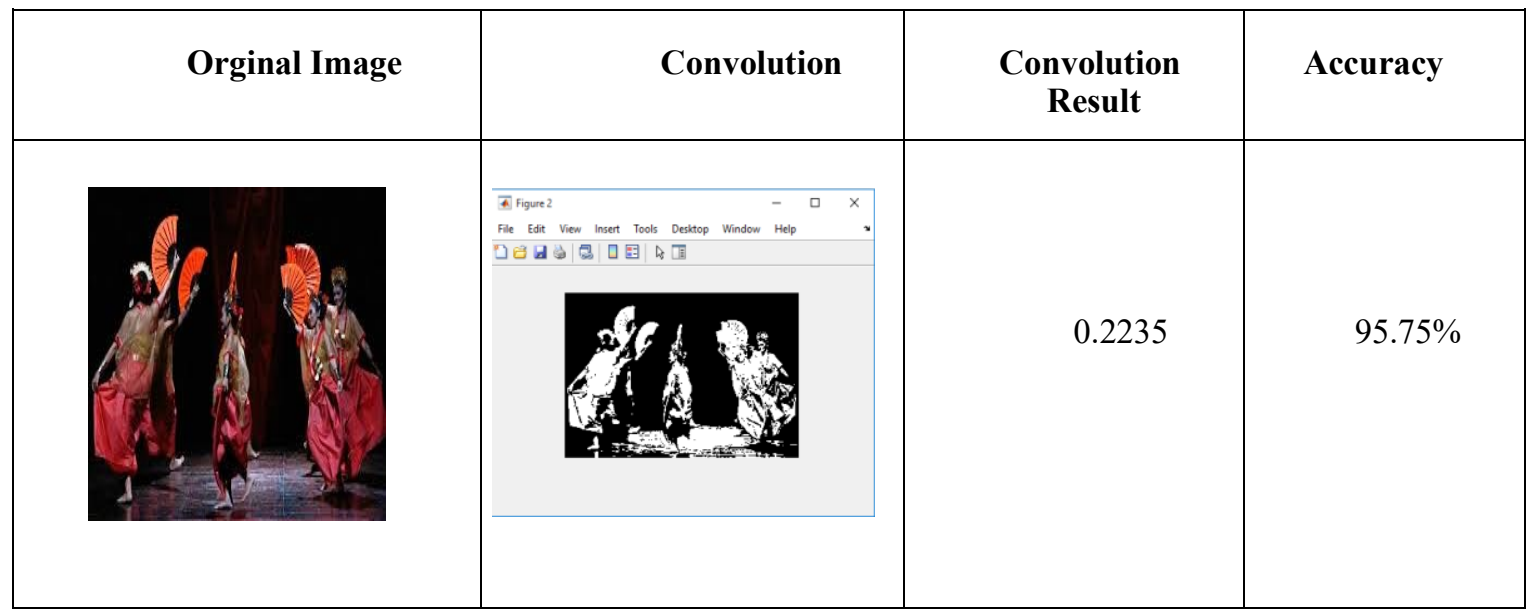

Based on Table 1 and Table 2 accuracy value is obtained from the first motion model when recording with low lighting conditions, the accuracy value is $80.15 \%$, the second movement model with small lighting has an accuracy of $88.82 \%$, the third movement model with small bright lighting has an accuracy of $90.18 \%$. While the fourth model of movement with bright lighting obtained an accuracy value of $95.75 \%$. It can be concluded that the pakarena dance movement is dominated by bright colors to get a good accuracy value [15][16]

Table 2. Accuracy Table

\begin{tabular}{|c|l|l|}
\hline Dance Model & $\begin{array}{l}\text { Recording } \\
\text { conditions }\end{array}$ & Accuracy \\
\hline Model1 & Lack of lighting & $80,15 \%$ \\
\hline Model2 & & \\
\hline Model3 & A little explanation & $88,82 \%$ \\
\hline Model & Small bright lighting & $90,18 \%$ \\
\hline & & \\
\hline B.ing & & \\
\hline
\end{tabular}

\section{Conclusion}

By classifying dance images using the CNN method, it is able to increase the intensity of the image lighting so that the image can be classified using a diagonal matrix of 0 and 1 . where the image with a diagonal matrix of 1 has brighter lighting. making it easy to classify dance images.

\section{References}

[1] R. Cioffi, M. Travaglioni, G. Piscitelli, A. Petrillo, and F. De Felice, "Artificial intelligence and machine learning applications in smart production: Progress, trends, and directions," Sustain., vol. 12, no. 2, 2020, doi: $10.3390 /$ su12020492

[2] W. S. Eka Putra, "Klasifikasi Citra Menggunakan Convolutional Neural Network (CNN) pada Caltech 101," J. Tek. ITS, vol. 5, no. 1, 2016, doi: 10.12962/j23373539.v5i1.15696. 
[3] E. N. Arrofiqoh and H. Harintaka, "Implementasi Metode Convolutional Neural Network Untuk Klasifikasi Tanaman Pada Citra Resolusi Tinggi,” Geomatika, vol. 24, no. 2, p. 61, 2018, doi: 10.24895/jig.2018.242.810 .

[4] A. N. H, M. Ichwan, and I. M. S. Putra, "Segmentasi Citra Untuk Deteksi Objek Warna Pada Aplikasi Pengambilan Bentuk Citra Rectangle,” J. Unpubl., pp. 1-10, 2015.

[5] M. Dahria, "Kecerdasan buatan (Artificial Intelligence),” J. SAINTIKOM, vol. 5, no. 2, pp. 1-10, 2008.

[6] I. Namatēvs, "Deep Convolutional Neural Networks : Structure , Feature Extraction and Training," vol. 20, no. December, pp. 40-47, 2017, doi: 10.1515/itms-2017-0007.

[7] D. E. Tarkus, S. R. U. A. Sompie, and A. Jacobus, "Implementasi Metode Recurrent Neural Network pada Pengklasifikasian Kualitas Telur Puyuh,” J. Tek. Inform., vol. 15, no. 2, pp. 137-144, 2020.

[8] J. Sturm, C. Stachniss, and W. Burgard, "A probabilistic framework for learning kinematic models of articulated objects," J. Artif. Intell. Res., vol. 41, pp. 477-526, 2011, doi: 10.1613/jair.3229.

[9] M. Z. Fawziah, Rumiwiharsih, and W. R. Ananda, "Function Shifts and Composition Form Reconstruction of Pakarena Dance,” vol. 444, no. Icaae 2019, pp. 190-195, 2020, doi: 10.2991/assehr.k.200703.038.

[10] M. Zufar, "Convolutional Neural Networks untuk Pengenalan Wajah Secara Real - Time," vol. 5, no. 2, pp. 72-77, 2016.

[11] A. Voulodimos, N. Doulamis, A. Doulamis, and E. Protopapadakis, "Deep Learning for Computer Vision: A Brief Review,” Comput. Intell. Neurosci., vol. 2018, 2018, doi: 10.1155/2018/7068349.

[12] H. J. A. Y. Siegel and L. J. Siegel, "PASM : for Image Processing and Pattern Recognition System,” vol. c, no. 12 , pp. 934-947, 1981.

[13] A. S. Kurniawan, "Implementasi Metode Artificial Neural Network Dalam Memprediksi Hasil Ujian Kompetensi Kebidanan (Studi Kasus Di Akademi Kebidanan Dehasen Bengkulu)," Pseudocode, vol. 5, no. 1, pp. 37-44, 2018, doi: 10.33369/pseudocode.5.1.37-44.

[14] M. Theresia, "the Markers of Politeness of Refusal in Penelope Movie," Tell-Us J., vol. 2, no. 2, pp. 56-77, 2016, doi: 10.22202/tus.2016.v2i2.1331.

[15] Y. A. Hasma and W. Silfianti, "Implementasi Deep Learning Menggunakan Framework Tensorflow Dengan Metode Faster Regional Convolutional Neural Network Untuk Pendeteksian Jerawat,” J. Ilm. Teknol. dan Rekayasa, vol. 23, no. 2, pp. 89-102, 2018, doi: 10.35760/tr.2018.v23i2.2459.

[16] V. Maha, P. Salawazo, D. Putra, J. Gea, F. Teknologi, and U. P. Indonesia, "Implementasi Metode Convolutional Neural Network ( CNN ) Pada Peneganalan Objek Video Cctv," J. Mantik Penusa, vol. 3, no. 1, pp. 74-79, 2019. 